Journal of Finance and Banking Review

Journal homepage: www. gatrenterprise. com/GATRJournals/index. html

J. Fin. Bank. Review 4 (1) 17-28 (2019)

\title{
Building Persistent Financial Performance
}

\author{
Sri Mulyantini
}

Universitas Pembangunan Nasional Veteran Jakarta, Jl RS Fatmawati, 12450, Jakarta, Indonesia

\begin{abstract}
Objective - The purpose of this study is to analyze profit persistence and the factors that influence it using secondary data from 39 banks listed on the Indonesian Stock Exchange in the form of pooled data, from 2008 to 2014.

Methodology/Technique - This study uses a purposive sampling technique, resulting in a sample of 31 banks. Variable profit persistence of each bank reflects sustainable earnings towards the industry in the future. The model determinant factors of persistence profit were analyzed by normalization models as reference models, average models and growth models as exploration models.

Findings - As a result, the persistence profit of banks listed on the Indonesian Stock Exchange tends to vary. Some banks have positive profit persistence (lambda) that reflects a competitive advantage in the long run. Other banks have a negative profit persistence, which reflects long-term competitive weakness.

Novelty - The ability to access capital and funding has a significant effect on profit persistence, although the direction of its influence is negative. Other variables, namely the capability to access public funds, the ability to innovate and industrial factors, namely credit market share, have a significant effect on persistent profits, while the ability to maintain asset quality and efficiency has no significant effect on profit persistence in banks listed on the Indonesian Stock Exchange.
\end{abstract}

Type of Paper: Empirical.

JEL Classification: G24, G32, G39.

Keywords: Financial capability, Innovation, profit persistence

\section{Introduction}

Sustainable finance is a challenge and opportunity for banks to grow and develop economic stability; when they have strategic resources that cannot be emulated by competitors and they are able to achieve profitability above the industry average (Barney, 1991); The banking industry in Indonesia plays an important role in the economic system, holding $76.06 \%$ of the total assets of all financial institutions.

\footnotetext{
* Paper Info: Received: December 15, 2018

Accepted: March 14, 2019

* Corresponding author: Sri Mulyantini

E-mail: srimulyantini61@gmail.com

Affiliation: Universitas Pembangunan Nasional Veteran Jakarta, J1 RS Fatmawati, 12450, Jakarta, Indonesia
} 
They also have play a role in the allocation of resources through the transfer of surplus funds to deficit parties (Allen \& Qian, 2014:499). They may help reduce transaction cost friction, asymmetric information, and credit portfolio management (Abdullah et. al., 2014:94; Bukhari et. al., 2012:1037). However, in economic growth, their role is not optimal; the ratio of loans to GDP and the deposit to GDP ratio are only $35.25 \%$ and $39.36 \%$ respectively. In addition, Indonesian banks are still weak in maintaining their long-term performance. Some previous research indicates that investors focus not only on high bank profits, but also persistent profits because this can be used as an indicator of future earnings (Tucker \& Zarowin, 2006). Appropriately, the magnitude of the persistence profit of banks in Indonesia is measured by lambda, is only 0.025 (Tarjizan \& Eyleerts, 2009); Goddard, Liu \& Molyneux (2010). This means that the position of the Indonesian banking industry and its ability to maintain long-term performance is relatively low compared to several other countries.

Table 1. Inter-Countries Persistence Profit Comparison

\begin{tabular}{|c|c|c|c|}
\hline Countries & Profit persistence & Countries & Profit persistence \\
\hline Indonesia & $0,025^{*} ; 0,038 \#$ & Thailand & $0,967 \#$ \\
\hline Australia & $0,255 \#$ & Chile & $0,32 \& ; 0,400 \#$ \\
\hline Bangladesh & $0,284 \#$ & Peru & $0,29 \& ; 0,328 \#$ \\
\hline China & $0,570 \#$ & Brazil & $0,23 \& ; 0,311 \#$ \\
\hline India & $0,477 \#$ & Argentina & $0,20 \& ; 0,164 \#$ \\
\hline Japan & $0,132 \#$ & Colombia & $0,33 \& ; 0,324 \#$ \\
\hline Malaysia & $0,122 \#$ & Mexico & $0,26 \& ; 0,512 \#$ \\
\hline Pakistan & $0,578 \#$ & USA & $0,27 \& ; 0,680 \#$ \\
\hline Singapore & $0,243 \#$ & & \\
\hline
\end{tabular}

Source: Data Processing Results (*), Tarjizan and Eyleerts, (2009) and Goddard, Liu and Molyneux (2010)

Other results show that maintaining persistence profits can be sought through improving financial capabilities and resources (Harrison, 2009:1; Chen et. al., 2014:563). This is caused by the ability and financial resources related to funding, investment, and asset management decisions that can maximize shareholder wealth in the long run (Horne \& Wachowicz, 2008:3 and 2012:2; Brigham \& Houston, 2012:2). The ability of companies to access the capital market and financing demonstrates the company's ability to maintain long-term performance (Fonseka et. al., 2014:963; Vorasubin, 2007:87). Profit persistence can also be maintained through consistent innovation (Roberts \& Amit, 2003:107; Lilly \& Juma, 2014:1; Atalay, 2013:226).

Developing and spreading the results of innovation improves a company's ability to survive, grow faster, be more efficient, and obtain greater profits (Atalay, 2013:226). Increased innovation can also be achieved through the ability to establish new relationships, build creativity and business synergy (Ojeda et. al., 2007:289; (Gaya et. al., 2013:1; Azorín et. al., 2015:41). Product development also has great potential for risk diversification, efficiency, and improving financial services (Allen, 2012; Frame \& White, 2004:166). In the context of innovation, collaboration activities not only occur by knowledge transfer, but also new knowledge creation, synergy solutions, and access to new resources (Frow et. al., 2014).

It is undeniable that financial innovation also creates risk (Huerta et. al., 2008) and waste of resources, (Studer, 2013:1). Moreover, the activity of launching new products in the initial stages will hamper sales due to the large expenditure required to develop the new product (Kotler, 1997:325). An in-depth study of the use of resources and financial capabilities involving human, physical, or organizational resources, which are mutually dependent, is required (Harrison, 2009:1; Chen et. al., 2014:563). 
Comprehensive financial capability variable models have not been developed thus far. Banking mostly takes place in manufacturing and other industries. Considering that research and development (R \& D) activities in the banking sector have not been seen, the existence and numbers are still small so there are no patents as in the manufacturing industry (Beck et. al., 2012). These problems contribute to the need for research aimed at identifying how to maintain profit persistence, through various determinants, namely the impact of financial capacity, innovation ability, and industry factors on profit persistence in the banking sector in Indonesia. A development of a theoretical model and further empirical studies are expected to identify how to increase profit persistence.

\section{Literature Review}

\subsection{Profit Persistence}

In many cases, investor attention not only produces high profits but persistent profits, which shows increasingly informative profits. Conversely, if profit is less persistent, it becomes less informative. Profit persistence refers to profit that can reflect sustainable earnings in the future (Penman, 2001). Profit persistence refers to the expected future earnings accounting revision caused by current earnings innovations (Penman \& Zhang, 2002:1; Scott, 2009).

Profit Persistence is profit that can be used as a measure of profit itself whereas current profit can be used as an indicator of future earnings (Tucker \& Zarowin, 2006). Profit persistence is the slope coefficient regression of current earnings on the lagged earnings, so that profit persistence is seen from the current year's profit innovations associated with changes in stock prices (Tucker \& Zarowin, 2006). The measurement model of profit persistence based on current earnings regression slope coefficient on lagged earnings has been widely used including by Lev and Thiagarajan (1983), Penman and Zhang (2002), and Pagalung (2006). Profit persistence is formally adopted from Mueller's model (1990a). There are two stages of modeling from the process of profit persistence analysis, using an analytical framework. These are:

Stage 1: Estimation of Profit Persistence

$$
\begin{aligned}
& \Delta \pi_{i t}=\theta_{i}+\sum_{k=0}^{\infty} \beta_{j, k} \mathrm{E}_{i, t-k}+u_{i, t} \ldots \ldots . .(1) \\
& E_{i t}=\theta_{i}+\sum_{k=i}^{\infty} \sigma_{j, k} \pi_{i, t-k}+e_{i, t} \ldots \ldots \ldots(2) \\
& \pi_{i t}=\breve{\pi}_{i}+\sum_{k=1}^{\infty} \lambda_{j, k} \pi_{i, t-k}+v_{i, t} \ldots \ldots .(3)
\end{aligned}
$$

Stage 2: Determinants of Profit Persistence Investigation

\subsection{Financial Capability}

The ability of companies to issue shares, non-convertibles and convertible bonds and to access finance demonstrates an ability to maintain long-term performance, (Fonseka et. al., 2014:963) or the ability to access capital, efficient cash management, and effective capital investment (Vorasubin, 2007:87). Companies with profits above normal levels are companies that have high barriers to entry and exit, while companies with below-normal profits have low barriers to entry and exit (McMillan \& Wohar, 2008). Factors related to higher earnings and persistence extend beyond the mere abilities of managers (Demerjian, 2013). 
The needs of capital companies through access to the capital market by selling shares, become a means of increasing good governance and company performance (Haque, 2006:1; Singh, 2000:1) increase control and efficiency (Singh, 2000:1); increase company value and R \& D (Kim \& Weisbach, 2005:3; Sosnowski, 2015:227). Problems arise for companies when placing stock positions in the capital market. Through the implementation of the two-board trading system as a result of the degradation to the development board is not a proud achievement of the issuers.

Funding through bond issuance is often important because it has a high probability of survival and is more profitable (Abor \& Kofi, 2009:195). Bond ratings are also important for investors because they show the scale of risk of default and provide an overview of credit worthiness which affects the value of selling bonds in the capital market. The higher the ranking, the higher the credibility of the bond is.

Likewise, the impact of the announcement of bond ratings such as rating downgrades is bad information for shareholders and bondholders (Goh \& Ederington, 1993, 2001). These have an impact on changes in stock prices (Liu, Seyyed \& Smith, 1999:337). The ability of banks to raise public funds in the form of third party funds (TPF) has an effect on credit distribution, which will also affect profit performance. The large ratio of deposits to assets and the ratio of deposits to loans are the main indicators of profitability (return on assets / ROA), (Bukhari et. al., 2012:1037; Dawood, 2014:1; Javaid et. al., 2011:59; Khan, 2011:1484).

Although commercial banks are able to increase finance using equity and debt, they typically mobilize third party funds (DPK) as financial resources, making their capital structure unique compared to other companies (Abdabi \& Abu-Rub, 2012:92; Taani 2013:41). The ability of banks to channel loans can increase profits (Bukhari, 2012:1037; Javaid, 2012:59; Khan \& Anuar, 2011:1484; Alpera \& Anbarb, 2012:139) through interest income and loan growth which contribute to bank profitability. In addition, it must also maintain Non-Performing Loans (NPL) as a proxy for credit quality management, as NPL has a positive effect on ROA (Paphayom \& Polwitoon, 2004:1578), but can also have a negative effect (Gelos, 2006:23). Efficiency is often proxied by the ratio of operating costs to operating income and has a negative effect on bank performance proxied by NIM and ROA, (Prabowo, 2001); (Abdullah et. al., 2014:82; Ilusmawati \& Nuswantara, 2014:1148).

\subsection{Innovation Capability}

Innovation in the financial sector is the act of creating and popularizing new financial instruments, new financial technologies, institutions and new financial markets. In addition, it can also be interpreted as the creation of financial instruments (both products and processes) with the discovery or diffusion of products, services or ideas. Banks that carry out activities that are innovative, consistent and different from industry norms, tend to display superior financial performance (Roberts \& Amit, 2008). Product innovation has a positive impact on revenue growth (Hassan et. al., 2013) and there are positive effects of innovation on company performance.

Technological innovation in the banking sector has an effect on employee performance, customer satisfaction and increased sustainable profitability (Dauda \& Akingbade, 2011) and the steps of strategic innovation adopted by banks greatly affect the performance of the bank (Lilly \& Juma, 2014). It can be concluded that innovation influences the measurement of innovation activities, which can be traced through innovative activity indicators, manufacturing industry innovation literature, focus on patents, $\mathrm{R} \& \mathrm{D}$ expenditures and share of research staff (Branstetter et. al., 2006).

Measuring innovation activities in the financial sector is more challenging because patents are rarely found (Frame \& White, 2004). Research in the European Union found that innovation does not have data related to spending on R \& D and research staff, because it is not documented for the benefit of financial institutions (Beck, 2012:1-9). This lack of data has hampered the study of financial innovation in several countries. Research by Thorsten Beck (2012:1-9) fills that gap. R \& D and collaboration activities are believed to be the main variables that drive the success of financial innovation, as measured by the percentage share of 
innovation. The measure of financial innovation has also been developed by Lerner (2006:2-4) who developed a measure of financial innovation based on announcements /news in the Wall Street Journal that reported the launching new products or new services.

\subsection{Industrial Factors}

Market share is the proportion or percentage of sales from a company (certain products) to all sales that occur in a particular market (Kotler, 2002:812). According to Assauri (2001:95), market share is the size of the part or the total area of the market that can be controlled by a company which is usually expressed as a percentage. Hence, market share is the size of the market that is controlled by a company, or the mastery of a product to the market or the amount of product demanded and produced by a company compared to the number of requests on the market.

The results of the study include industrial factor input variables namely credit market share by revealing the problem of the output variable and how to maintain profit persistence that market share has an impact on the profitability of commercial banks (Muthini, 2013). Bank profits are determined by a larger market share (Garza-Garciab, 2010). All bank factors have a statistically significant impact on profitability however, there are no market factors that have a significant impact (Olweny \& Shipho, 2011). Previous research on the impact of industrial factors on profit persistence is scarce.

\section{Research Methodology}

The object of this study is profit persistence and the factors that influence it, namely: financial ability, innovation ability and industry factors in banks listed on the Indonesian Stock Exchange (IDX) for the period between 2009 and 2014. The type of data collected is secondary data, in the form of pooled data. The research population is all banks listed on the Indonesian Stock Exchange, which amounts to 39 banks.

\subsection{Dependent Variables}

The dependent variables include profit persistence, measured by persistence of abnormal profitability based on empirical data on company profit dynamics, and estimated through dynamic panel regression analysis at the banking company level, as the theory of persistence of profit hypothesis (Mueller, 1977, 1986).

\subsection{Independent Variable}

The independent variables are the determinants of profit persistence including financial capability consisting of the ability to access capital, which is the ability to access share capital and bonds, the ability to access public funds, which is the ability to maintain quality assets, as well as the ability to maintain efficiency. In addition, innovation capability, consisting of the ability to expand networks, increase size, launch new products and collaborate, empowering training and R \& D. Furthermore, Industrial factors are variables used for the ability to reach the Credit Market.

\subsection{Analysis Techniques}

The analysis technique for measurement of inter-bank profit persistence and the factors that influence it is a linear regression with a two-stage approach (two-step approach), based on the model developed by Goddard, Liu, Molyneux and Wilson (2010), and relies on the persistence theory based on Mueller's profit hypothesis $(1977,1986)$. The first stage involved analyzing the level of profit persistence of each bank 
between 2009 and 2014, which is estimated through the inter-year time-series regression results based on bank first-order autoregressive profitability models, which are normalized in dynamic panel formation. Bank profitability is measured by Return on Assets (ROA), while normalized bank profitability is a deviation between the ROA of a bank and the annual inter-bank ROA (abnormal ROA). The measurement of profit persistence throughout the study period (2009-2014) of each bank is:

$\pi_{\mathrm{i}, \mathrm{t}}=\pi_{\mathrm{i}}^{2}+\lambda_{\mathrm{i} \cdot} \cdot \pi_{\mathrm{i}, \mathrm{-}-\mathrm{1}}+\mathrm{v}_{\mathrm{i}, \mathrm{t}}$

$\pi_{\mathrm{i}, \mathrm{t}}=$ the ROA deviation of the-i bank with the average inter-bank ROA for the year-t $\left(\mathrm{ROA}_{\mathrm{i}, \mathrm{t}}-\mathrm{ROA}_{\mathrm{t}}{ }^{2}\right)$

$\pi_{\mathrm{i}, \mathrm{t}-1}=$ the ROA deviation of the-i bank with the average inter-bank ROA for the year- $\mathrm{t}-1\left(\mathrm{ROA}_{\mathrm{i}, \mathrm{t}-1}-\mathrm{ROA}_{\mathrm{t}-1}{ }^{-}\right)$

$\pi_{\mathrm{i}}^{\tilde{}}=$ estimation of the model constant, which shows the average ROA deviation of the-i bank with the average ROA between banks in the long run

$\lambda_{\mathrm{i}}=$ estimation of the model regression coefficient, shows the persistence of profit as a proxy for profit persistence from the-i bank

In the second stage, the regression coefficient results of the first stage autoregressive first-order model estimation, namely persistence profit treated as a dependent variable, are measured in a cross-sectional regression analysis between banks based on the factors suspected to influence it. The regression equation model in the second stage of the regression analysis is a model of the effect of financial ability, innovation ability and industrial factors on profit persistence analyzed in relation to the research hypothesis test. The regression equations analyzed are:

$\lambda_{i}=b_{0}+\sum b_{j} \cdot X_{j i}+e_{i}$

$\lambda_{i}=b_{0}+b_{1} \cdot X_{1 i}+b_{2} \cdot X_{2 i}+b_{3} \cdot X_{3 i}+b_{4} \cdot X_{4 i}+b_{5} \cdot X_{5 i}+b_{6} \cdot X_{6 i}+b_{7} \cdot X_{7 i}+b_{8} \cdot X_{8 i}+b_{9} \cdot X_{9 i}+b_{10} \cdot X_{10 i}+b_{11} \cdot X_{11 i}+$ $b_{12} \cdot X_{12 i}+b_{13} \cdot X_{13 i}+b_{14} \cdot X_{14 i}+e_{i}$

$\mathrm{LAMBDA}_{\mathrm{i}}=b_{0}+b_{1} \cdot S Q_{i}+b_{2} \cdot S F_{i}+b_{3} \cdot B Q_{i}+b_{4} \cdot B F_{i}+b_{5} \cdot T P F_{i}+b_{6} \cdot L D_{i}+b_{7} \cdot C Q_{i}+b_{8} \cdot$ OCTOI $_{i}+b_{9} \cdot A B_{i}+$ $b_{10} \cdot F Z_{i}+b_{11} \cdot L N P+b_{12} \cdot A C_{i}+b_{13} \cdot$ OTCRDTIR $_{i}+b_{9} \cdot C M S_{i+} e_{\mathrm{i}}$

where:

$\lambda_{\mathrm{i}}(\mathrm{LAMBDA})=$ profit persistence from the-i bank

$\mathrm{X}_{\mathrm{ji}}=$ the-j independent variable from the-i bank

$\mathrm{X} 1 \mathrm{i}$ s/d X8i = independent variable 1st -9 th as influencing factors profit persistence from the-i bank, consisting of : SQ (Stock Quality); SF (Stock Fund); BQ (Bond Quality); BF (Bond Fund); TPF (Third Party Fund); LD (Loan Distributed); CQ (Credit Quality); OCTOI (Ratio of Operational Cost against Operational Income); $\mathrm{AB}$ (Amount of Branch); FZ (Firm Size); LNP (Launching New Product); AC (Amount of Collaboration); OTCRD to TIR (Outsourcing, training cost, and R\&D to Total Income Ratio); CMS (Credit Market Share).

$\mathrm{b} 0=$ estimation of the model constant, which shows the average profit persistence in the long run.

$\mathrm{bi}=$ estimation of the model regression coefficient, which shows the sensitivity of profit persistence to changes in the $\mathrm{j}$-independent variable.

The determinative model of profit persistence is analyzed through three (3) measurement models, namely: normalization model as a reference model, as well as the average model and growth model as an exploration model. Each measurement model is analyzed by two (2) methods, namely: enter method and backward method. In the enter method, the model is analyzed by including all of the independent variables whereas in 
the backward method, the model is analyzed in stages by removing the independent variables that do not meet the significance of the $10 \%$ model and include the independent variables that meet the significance of the 5\% model. Before being analyzed, the model of the influence of financial ability, and industrial factors on profit persistence in the enter method normalization model, which was first tested for its suitability with the classical assumption for multiple linear regression requirements. Test assumptions include tests of normality, multicollinearity and heteroscedasticity. The autocorrelation test is not included as the data formation is cross-sectional which has no particular sequence.

\section{Results}

The first-order auto regressive (AR (1)) model of bank profitability normalized in dynamic panel formation, is used to measure bank profit persistence throughout the study period (2008-2014) in each bank.

Table 2. Banks with Positive and Negative Persistence Profit

\begin{tabular}{|c|c|c|c|c|c|}
\hline $\begin{array}{c}\text { Ban } \\
\mathbf{k}\end{array}$ & PHIi & $\begin{array}{c}\text { Positive Lambda } \\
(\lambda)\end{array}$ & Bank & PHIi & Negative Lambda $(\lambda)$ \\
\hline 1 & $(0.473)$ & 0,024 & 5 & 2.018 & $(0,005)$ \\
\hline 2 & $(1.843)$ & 0,151 & 8 & $(0.241)$ & $(0,118)$ \\
\hline 3 & $(0.570)$ & 0,009 & 9 & 4.490 & $(0,450)$ \\
\hline 4 & $(0.471)$ & 0,541 & 11 & $(2.980)$ & $(0,082)$ \\
\hline 6 & $(0.032)$ & 0,048 & 12 & 0.903 & $(0,329)$ \\
\hline 7 & 0.632 & 0,526 & 16 & 1.930 & $(0,067)$ \\
\hline 10 & 0.065 & 0,017 & 18 & 1.203 & $(0,330)$ \\
\hline 13 & $(3.648)$ & 0,385 & 19 & $(0.500)$ & $(0,368)$ \\
\hline 14 & 0.348 & 0,442 & 21 & $(0.274)$ & $(0,236)$ \\
\hline 15 & $(1.372)$ & 0,188 & 22 & 1.671 & $(0,103)$ \\
\hline 17 & 0.174 & 0,183 & 23 & 3.113 & $(0,236)$ \\
\hline 20 & $(0.104)$ & 0,067 & 24 & 0.156 & $(0,298)$ \\
\hline 29 & $(0.032)$ & 0,222 & 25 & $(0.929)$ & $(0,088)$ \\
\hline 30 & 0.162 & 0,115 & 26 & 0.233 & $(0,124)$ \\
\hline 28 & $(0.962)$ & 0,026 & 27 & $(0.422)$ & $(0,163)$ \\
\hline & & & 31 & 1.028 & $(0,016)$ \\
\hline
\end{tabular}

Source: Data Processing

The results of the measurement of profit persistence indicate that banks with high ROA do not guarantee a high persistence of profit and vice versa. Hence, banks with a high ROA have a negative profit persistence which indicates of long-term performance weakness because they are unable to maintain the achievement of relative abnormal ROA compared to the industry average ROA. Bank number 9 throughout the period 20092014 produced the highest average ROA compared to other banks, which amounted to $4.7 \%$. However, that bank also has the lowest profit persistence. 
Bank number 5 in the period 2009-2014 has the highest average ROA of the third rank after bank number 9 and bank number 24, which is equal to $3.67 \%$. However, bank number 5 also has a negative profit persistence. Thus, banks with low ROA can have positive profit persistence that shows the ability to maintain long-term performance, because it is able to maintain the achievement of abnormal ROA-compared to the industry average ROA. Bank number 4 throughout the period of 2009-2014 ranked $21^{\text {st }}$ for ROA, compared to the other banks, which amounted to $1.33 \%$. However, that bank also has the highest profit persistence. Bank number 3 in the period 2009-2014 ranked $25^{\text {th }}$ for ROA, which is equal to $1.09 \%$. That bank also has a positive profit persistence.

Table 3. The Result of Normalization, Average and Growth Model of Regression Analysis

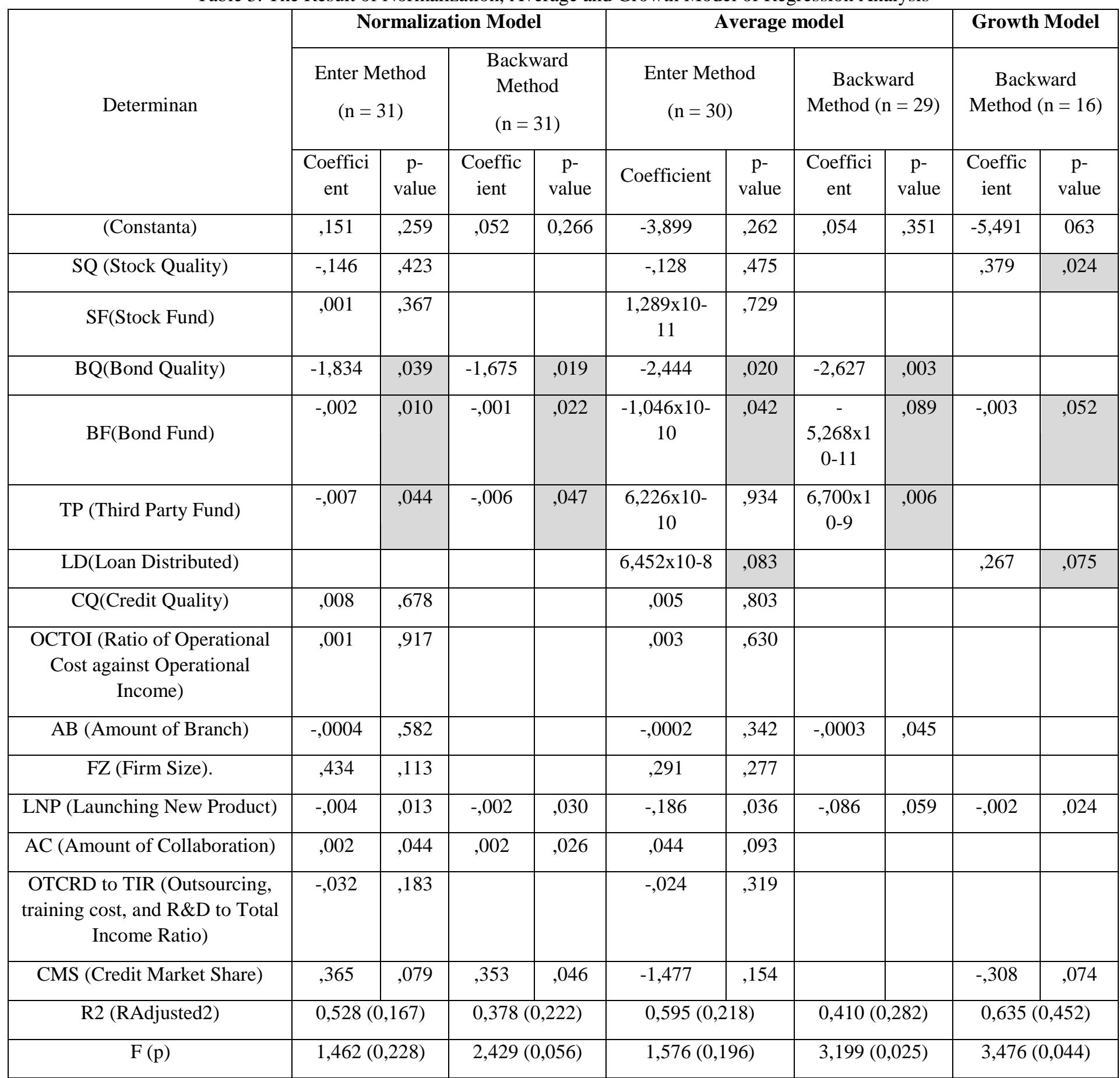

Source: Data Processing 
The results of the normalization model analysis as a reference model and the average model and growth model as an exploration model are shown in Table 2. The results show that the model analysis of the influence of financial ability, innovation ability, and industry factors on banking profit persistence with normalization models is robust. In both the enter method and backward method, the factors that significantly influence the banking profit persistence are Bond Quality (BQ), Bond Fund (BF), Third Party Funds (TPF), and Credit Market Share (CMS).

Hence, it can be concluded that the determinants of profit persistence on banks listed on the Indonesian Stock Exchange are Bond Quality (BQ), Bond Fund (BF), Third Party Funds (TPF), and Credit Market Share (CMS). Bond Quality (BQ) consistently has a significant effect on banking profit persistence in the average model, based on both the enter method and backward method. The effect of Bond Quality (BQ) on banking profit persistence has a negative direction. Bond Funds (BF) has a significant effect on profit persistence with the average model, in both the enter method and backward method, and growth models based on the backward method.

The effect of the Bond Fund (BF) on profit persistence is equally negative. Third Party Funds (TPF) also has a significant effect on the average model with the backward method however, the effect is the opposite in the normalization model. The influence of Third Party Funds (TPF) on the normalization model has a negative direction, while the influence of Third Party Funds (TPF) on the average model based on backward methods has a positive direction. Meanwhile, Credit Market Share (CMS) also has a significant effect on the growth model based on the backward method however, the direction of influence is the in the normalization model. The effect of Credit Market Share (CMS) on the normalization model has a positive direction, whilst the influence of Credit Market Share (CMS) in the growth model based on the backward method is negative.

\section{Discussion}

That three strategic assets (access to capital, efficient cash management and effective capital investment) were found to contribute to profit persistence in construction companies in Thailand (Vorasubin \& Chareonngam, 2007). Hence, stock issuance is positively related to bank profitability and liquidity (Behery \& Eldomiaty, 2010:120), based on the analysis of the effect of Financial Capability and Industry Factors on profit persistence in the normalization model.

It can be concluded that profit persistence in banks listed on the Indonesian Securities Exchange is significantly affected by the ability to access capital and funding. In this case, the ability to access funding (Bond Quality (BQ) and Bond Funds (BF), Bond Quality (BQ) and Bond Fund (BF)) has a negative effect on profit persistence. These results show that banks with better ability to access bonds, as indicated by the rating of bonds and the higher amount of bond funds, tend to be less able to utilize it to achieve profit persistence.

Increased capital capacity from long-term debt (bonds), in addition to the potential to maintain and achieve higher income, may also cause an increase in the cost of capital. Additional or less productive capital, high capital costs and low capital income aggregately affect a decrease in profit persistence. In line with the results of Dawar (2014), there is a negative influence on financial performance. Garralda (2014) further argues that an increase in bond debt without a positive bondholder investment profile and sound financial condition of the borrowing company and conducive monetary conditions has the potential to trigger losses on various parties and reduce financial stability.

To achieve profit persistence, Vorasubin and Chareonngam (2007) require efficient cash management and effective capital use, in addition to access to capital. Cotei et. al. (2011:715) state that debt use increases a company's exposure to financial risk. In conditions of high business risk, companies with more debt have a higher risk of loss. The research hypothesis concerning the effect of the ability to access public funds on profit persistence in the normalization model conclude that bank profit persistence is significantly influenced by the ability to access public funds (Third Party Funds (TPF)) which negatively affects profit persistence. 
This shows that banks with better access to public funds tend to be less able to use them to achieve profit persistence.

The increased capital capacity of the TPF, in addition to the potential to maintain and achieve higher income, may also increase the cost of capital. In conditions of additional or less productive capital, high capital costs and low income on capital all have an effect on the low persistence of profits. This may result in low bank prudence in managing deposit funds effectively and efficiently due to the low supervision relative to managing debt funds and/or equity.

The research hypothesis concerning the effect of the ability to maintain asset quality against profit persistence based on the normalization model concludes that bank persistence profit is not significantly affected by the ability to maintain asset quality (Distributed Credit (LD) and Credit Quality (CQ)). The research hypothesis concerning the effect of the ability to maintain efficiency on profit persistence was tested based on the analysis of the effect of financial ability and Industry Factors on profit persistence in the normalization model (BOPO).

The research hypothesis concerning the influence of industry factors on the normalization model concludes that profit persistence is influenced significantly by industry factors (Credit Market Share (CMS)). Credit Market Share (CMS) has a positive effect on profit persistence. This demonstrates that banks with better industrial factor positions, indicated by higher credit market shares, tend to be better able to use them to achieve profit persistence.

Increasing credit market share in the banking industry, in addition to the potential to gain higher income, may also cause an increase in costs. In conditions of credit that are productively distributed with a low risk of default and the ability of the company to reduce its credit risk through credit diversification, an increase in their credit market share can increase credit income, which has implications for the high persistence of corporate profits.

Hughes and Mester (2013) argue that the ability of banks to diversify credit and manage liquidity risk is a factor that determines the bank's profit persistence in providing financial products and services with various rules. The results of this study are consistent with the results of Buyinzal and Bbaale1 (2013) which shows that companies that have better access to credit and increased loans with longer duration can produce higher company performance.

\section{Conclusion}

Based on the research problem and objectives, the results of the research and discussion conclude that the profit persistence of banks listed on the Indonesian Stock Exchange tend to vary. Some banks have a positive persistence of profit (lambda) that reflects profit in the long run, while some other banks have a negative profit persistence that indicates an inability to maintain profit in the long run. The Determinant of Profit persistence of banks listed on the Indonesian Stock Exchange is the ability to access funding, which is the quality of bonds and bond funds, the ability to access public funds, which is third party funds, and industry factors, which includes credit market share.

The ability to access capital and funding has a significant effect on profit persistence in banks listed on the Indonesian Stock Exchange, although the effect is negative. In conditions of high business risk, the increasing quality of corporate bonds and mobilization of bond funds is not accompanied by an increase in efficient cash management and effective use of capital which is counter-productive in encouraging banking profit persistence.

The ability to access public funds has a significant effect on profit persistence and increase third party funds, which counter-productive to encouraging banking profit persistence due to the low level of prudence in managing deposit funds effectively and efficiently, relative to the management of debt funds and/or equity. The ability to maintain asset quality has no significant effect on profit persistence. 
The ability to maintain efficiency does not have a significant effect on profit persistence, and the Ratio of Operational Cost against Operational Income (OCTOI) is not a determinant of banking profit persistence. Further research may wish to review this research model by considering the factors of financial capacity, innovation capability, and other industrial factors that have not been studied by replicating the research model at the industrial level that positions banking as one of its sectors and the state level that positions Indonesia as one of the analysis unit references.

\section{References}

Ajit Singh (2003). Corporate Governance, Corporate Finance and Stock Markets in Emerging Countries. ESRC Centre for Business Research, University of Cambridge Working Paper 258.

Abor Joshua, Emmanuel Sarpong-Kumankoma, Eme Fiawoyife and Kofi A. Osei, (2009). Risk Exposure and Financial Policy: An Empirical Analysis of Emerging Markets. Journal of Economic Studies, 36(2), 195-211.

Abdullah AL-Mutairi and Kamal Naser (2015) Determinants of Capital Structure of Banking Sector in GCC: An Empirical Investigation. Asian Economic and Financial Review, 2015, 5(7), 959-972.

Barney, J. (1991). Firm Resources and Sustained Competitive Advantage. Journal of Management. 17(1), 99-120.

Bukhari S. A. J and Qudous R.A (2012). Internal and External Determinants of Profitability of Banks: Evidence from Pakistan.

Chen Lucy Huajing, David M. Folsom, Wonsun Paek and Heibatollah Sami (2014). Accounting Conservatism, Earnings Persistence and Pricing Multiples on Earnings. Accounting Horizons, 28(2), 233-260.

Haque F, Thankom A, Colin K (2006) Corporate Governance and Capital Markets: Conceptual Framework. HeriotWatt University Dubai Campus, Dubai Academic City.

Fonseka, Xing Yang, Gao liang Tian, (2013). Does Accessibility To Different Sources of Financial Capital Affect Competitive Advantage And Sustained Competitive Advantages? Evidence from a Highly Regulated Chinese Market. The Journal of Applied Business Research, 29, 963-982.

Franklin Allen \& Jun "QJ" Qian (2014). China's Financial System and the Law. Cornell International Law Journal Vol. 47

Frame W. Scott and White Lawrence J. (2009-10). Technological change, financial innovation, and diffusion in banking. Working Paper

Gaya (2013). African Journal of Business Management Vol. 7(21), pp. 2049-2058, 7 Jun Financial and Quantitative Analysis, Vol. 36 No. 1, pp. 1-24

Goddard, John - Liu, Hong; Molyneux, Phil Wilson, John O.S. (2011).“The Persistence of Bank Profit”, Journal of Banking and Finance, 35, pp. 2881-2890.

Goddard, J., Molyneux, P., Liu, H., and Wilson, J.O.S. (2010b). The persistence of bank profit, St Andrews Management School Working Paper.

Jose F. Molina- Azorín et al (2015), The effects of quality and environmental management on competitive advantage: A mixed methods study in the hotel industry Tourism Management Volume 50, Pages 41-54

Jerop Lilly, Dennis Juma (2014). Influence Of strategic innovation on performance of commercial banks in Kenya. European Journal of Business Management Vol.2, Issue 1

Jennifer W. Tucker and Paul A. Zarowin (2006). Does Income Smoothing Improve Earnings Informativeness? The Accounting Review Vol. 81, No. 12006 pp. 251-270

Lev, B. and R., Thiagarajan, (1993). Fundamental Information Analysis. Journal of Accounting Research, 31 (2), 190 215.

McMillan, David G. Wohar, Mark E. (2011), "Profit Persistence Revisited: The Case of the UK", The Man-hester School , 79(3), 510-527.

Mueller D. 1997. "The persistence of profits above the Norm”. Economica, New Series, Volume 44, 176, pp. 369-380.

Ojeda Julieta-Gomez Mike, Simpson S.C, Lenny Koh Jo Padmore, (2007). Achieving competitive advantage in the Mexican footwear industry", Benchmarking: An International Journal, Vol. 14 Iss 3 pp. $289-305$.

Penman, S.H. and X.J. Zhang. (2002). Accounting Conservatism, the Quality of Earning and Stock Returns. Working Paper, www. ssrn.com

Pagalung, G. "Quality of earnings: The determinants and economic consequences." Dissertation, Gajah Mada University Yogyakarta, 2006. 
Roberts, P.W. and R. Amit, (2003). The dynamics of innovative activity and competitive advantage: the case of Australian retail banking, 1981 to 1995”. Organization Science , 14 (2),pp. 107-122

Sosnowski Tomasz (2015). Motives and Effects of the Initial Public Offerings stock Exchange. Quarterly Journal of Economics and Economic Policy. vol. 10, issue 2, pages 207-222

Studery, Sabrina (2013). A Real Economy with Banking and Financial Innovations: Diversification vs. Volatility. University of Zurich, Department of Economics,

Tarzijan, Jorge,Brahm, Francisco D, Luis Felipe. (2008). "Entrepreneurial Profitability and Persistence: Chile versus the U.S.A.”, Journal of Business Research, 61, pp. 599-608.

Tucker, J. and Zarowin, P. (2006) Does Income Smoothing Improve Earnings Informativeness? The Accounting Review, 1, 251-270

Vorasubin, P. and Chareonngam, C. (2007). Strategic assets driving financial capability of Thai construction firms. Journal of Financial Management of Property and Construction, 12 (2), 87-94.

Brigham, Eugene F., Joel F. Houston. (2012). Fundamentals of Financial Management. Concise Edition

Brealy, Richard A and Steward C. Myers. 1991. Pinciple Of Couporate Finance . Fourth Edition. Megraw -Hill, Inc

Mueller D. Profits and the process of competition. The dynamic of profits. An international comparison, Cambridge University Press, 1990 a.

Mueller, D. C. (1986). Profits in the Long Run. Cambridge: Cambridge University Press

Myers, S.C., (1984). The capital structure puzzle. Journal of Finance 39, 575-592

Myers, S.C. and Majluf, N.S. (1984), "Corporate financing and investment decisions when firms have information that investors do not have", Journal of Financial Economics, Vol. 13 No. 2, pp. 187-221.

Van Horne James C., Wachowicz John M., Jr (2008). Fundamentals of Financial Management.13th Edition. 